\title{
ニューラルネットワークを併用した適応制御
}

\author{
辻 純一*・大森 浩 充*・佐 野 昭*
}

\section{Adaptive Control Incorporating Neural Network}

\author{
Junichi TsujI*, Hiromitsu OHMORI* and Akira SANO*
}

\begin{abstract}
This paper presents a new structure of nonlinear adaptive control system incorporating a neural network $(\mathrm{NN})$. The control input is given by the sum of the output of a robust adaptive controller and the output of the NN. The role of the $\mathrm{NN}$ is to compensate for constructing a linearized model so as to minimize an output error caused by nonlinearities in the controlled system. The role of the robust adaptive controller is to perform the model-matching for the uncertain linearized system to a given linear reference model. One of the distinctive features of the proposed structure is to give an efficient method for calculating the derivative of the system output with respect to the input by using one identified parameter in the linearized model and the internal variables of the $\mathrm{NN}$, which enables to perform the back-propagation algorithm very efficiently. In numerical simulations, we examine the effectiveness of the proposed scheme by applying it to a variety of nonlinear systems, such as a system with backlash.
\end{abstract}

Key Words : neural network, adaptive control, nonlinear control, intelligent control.

\section{1. はじめに}

ニューラルネットワーク(以下, NN と略記する)は, パターンの学習や識別などに有効な手法として近年ブー ムを引き起こしたが1), その後, ダイナミクスをもつ制御 系への応用も盛んに試みられるようになった22. 今まで に提案された有力な方法の一つに，制御対象の逆システ ムを構成するフィードフォワード補償器を NN で実現 し, それをフィードバック誤差学習法で学習する川人ら の方法がある ${ }^{3)}$.さらに,フィードバック補償器を NNで 構成する方法も考えられたが，制御系の場合，パターン 認識などの場合と異なり, NN と学習に必要な出力誤差 の間に未知の制御対象が存在するため, NN をバックプ ロパゲーション法で学習する際に, 入力に関する出力の 微分係数すなわちヤコビアンの情報が必要となる. しか し微分係数の効果的な計算方法がないため, 多大な計算 時間や学習時間が必要になるという問題が指摘されてい る.一つの解決策は, 未知制御対象の非線形系をまず

†第 21 回制御理論シンポジウムで発表 $(1992 \cdot 5)$

* 慶應義塾大学理工学部 横浜市港北区日吉 3-14-1

* Faculty of Science and Engineering, Keio

University, Yokohama

(Received April 20, 1993)

(Reviced July 27, 1993)
NN により同定することにより (順モデルの構成 $)^{4), 5)}$, 前 記の微分係数を計算し，これを利用してさらにもう一つ の NN を用いた逆モデルによる制御を組み合せるとい う，いわば間接的な方法が非常に多く提案されてい る6) 11).また，NNによる同定を介さずに直接，NNで 制御器を構成できることも明らかにされている が12) 14), 実際にはやはり効率のよい学習法が必要とされ ている.

本論文では，NNに非線形系を線形化する機能をもた せ，線形化されたモデルに対してロバストなモデル規範 形適応制御器を構成する新しい構造をもつ制御系を提案 する，この方法の最大の特徵は，NNの学習の際に必要 な非線形系の入力に関する出力の微分係数を, 線形化さ れたモデルのゲイン係数と NN の内部状態とを用いて 容易に計算できる点にある。これによりバックプロパ ゲーション法をきわめて効率よく実施することができ る.また，提案する構造においては，NN に主に非線形 性を補償する機能をもだせており，制御対象が線形であ れば，NN はほとんど動作しないという特徵がある．制 御対象が線形系に近ければ, 線形系に対する適応制御器 が主に機能することからも効率の高い構成法といえる。 また NN は 1 個で斉む点も大きな利点といえる，最後 に，各種の非線形特性の補償に関する適用例をとおして 
提案の手法の有効性を検討する.

\section{2. ニューラルネット $(\mathrm{NN})$ に基づく適応制御}

\subsection{NN を用いたシステム表現}

非線形の制御対象の入出力特性が

$$
\begin{aligned}
y(k)= & f(v(k-L), \cdots, v(k-L-m), \\
& y(k-1), \cdots, y(k-n))
\end{aligned}
$$

で表わされるとする.ここで, $L$ は既知のむだ時間, $v(k)$, $y(k)$ はそれぞれ入力, 出力を表わす.いま, 時刻 $k-L$ を 基準として, $y(k-L), y(k-L+1), \cdots, y(k-1)$ を順次消 去すると

$$
\begin{aligned}
y(k)= & g(v(k-L), \cdots, v(k-L-m), \\
& y(k-L-1), \cdots, y(k-L-n))
\end{aligned}
$$

なる形に変形できる.ここで, $y(k)$ と $v(k-L)$ との間に 1 対 1 対応を仮定し, $g(\cdot)$ の逆関数 $h(\cdot)$ を用いると, 制御対象の入力表現形式は

$$
\begin{aligned}
v(k-L)= & h(y(k), v(k-L-1), \cdots, v(k-L-m), \\
& y(k-L-1), \cdots, y(k-L-n))
\end{aligned}
$$

で与えられる(13,14). ここで $h(\cdot)$ は括弧の中を変数とす る多変数未知非線形関数である。これを階層形 $\mathrm{NN}$ によ り $\hat{h}(\cdot)$ でモデル化すると，NN のモデル出力は

$$
\begin{aligned}
\hat{v}(k-L)= & \hat{h}(y(k), v(k-L-1), \cdots, v(k-L-m), \\
& y(k-L-1), \cdots, y(k-L-n))
\end{aligned}
$$

で表わされる．NN の重みは， $(3)$ 式と（4) 式の間の二 乗誤差 $(v(k-L)-\hat{v}(k-L))^{2}$ の累積和を小さくするよ うに調整される。(4)式の NN が同定されると, 出力 $y(k+L)$ を規範出力 $y_{r}(k+L)$ に一致させる制御入力 は,

$$
\begin{aligned}
v(k)= & \widehat{h}\left(y_{r}(k+L), v(k-1), \cdots, v(k-m),\right. \\
& y(k-1), \cdots, y(k-n))
\end{aligned}
$$

のように構成される。

( 5 ) 式を実行する制御器は入力と出力の過去の值およ
び規範出力の未来值を入力とする NN であり,この構造 ほ適応制御の非線形系への自然な挔張として捉えること ができる ${ }^{13), 14)}$.しかし,このような直接的方法は実際に適 用してみると学習に非常に多くの時間が必要となり，何 らかの工夫が必要となる。本論文の目的は，直接法の立 場からバックプロパゲーション法を効率よく実施する一 つの有力な方法を与えることにある。

\section{$2.2 \mathrm{NN}$ を含む新しい非線形適応制御}

Fig. 1 に, 本論文で提案する NN を組み込んだ新しい 制御構造を示す. 制御目的は, 規範入力 $r(k)$ から制御出 力 $y(k)$ までの入出力特性を線形の規範モデルに一致さ せることである，適応制御器は線形系に対するモデル マッチングを基礎としたものであり，適応アルゴリズム は不感帯を導入したロバスト調整則を採用している。一 方，図示したように NN と非線形系とを組み合せた点線 内の系が線形となるように NN の重みを調整するとい う構造をもっている. NN の重みは出力誤差 $e(k)=y(k)$ $-y_{r}(k)$ をゼロにする方向に調整される。本構造の大き な特徵は, 制御入力 $v(k)$ が, ロバスト適応制御器の出力 $u(k)$ と NN の出力 $\bar{u}(k)$ の和で与えられる点にある.

したがって, $y(k+L)$ を $y_{r}(k+L)$ に追従させる制御 入力を $(3)$ 式から求めることにより，NN の出力はつぎ のように表わせる。

$$
\begin{aligned}
\bar{u}(k)= & h\left(y_{r}(k+L), v(k-1), \cdots, v(k-m),\right. \\
& y(k-1), \cdots, y(k-n))-u(k) \\
= & h_{f}\left(u(k), y_{r}(k+L), v(k-1), \cdots, v(k-m),\right. \\
& y(k-1), \cdots, y(k-n))
\end{aligned}
$$

結局 NN の目的は, (6) 式右辺の非線形関数を実現する ことになる. $h_{f}(\cdot)$ の括弧の中の変数が $\mathrm{NN}$ への入力変 数として最低限必要であることがわかる. NN の学習は 後述するように, 出力誤差 $e(k)$ をゼロにするように NN の重みを調整することにより行われる.

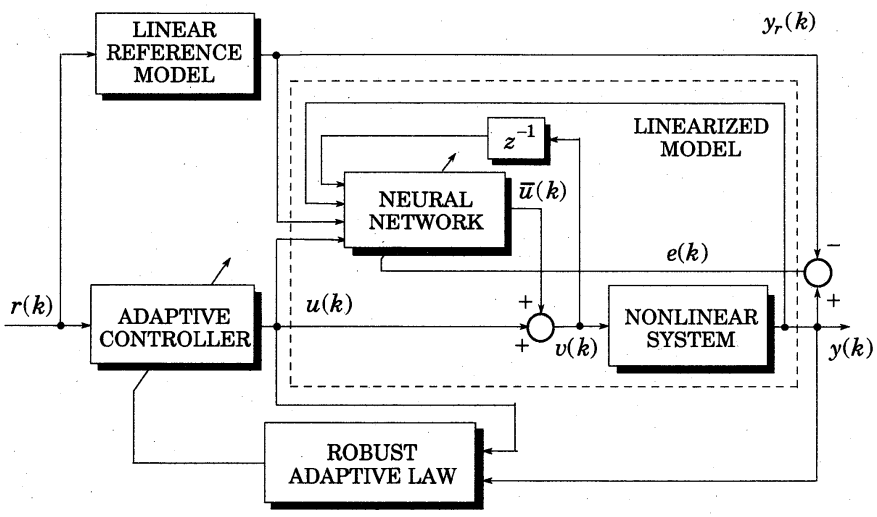

Fig. 1 Schematic diagram of proposed nonlinear adaptive control system incorporating neural network 
また, 多少直観的ではあるが, 文献 15)では, 時刻 $k よ$ り将来の出力 $y(k+j)$ を規範出力 $y_{r}(k+j)$ で置き換え るという考え方にたつと,（6)式の表現は,

$$
\begin{aligned}
\bar{u}(k)= & h_{f}\left(u(k), y_{r}(k+L), v(k-1), \cdots, v(k-m),\right. \\
& \left.y_{r}(k+L-1), \cdots, y_{r}(k+L-n)\right)
\end{aligned}
$$

となり, $\mathrm{NN}$ への入力変数も代わる.このような構成で も以下の議論は同様に成り立つ.

\section{3. 線形化システムに対するロバスト適応制御}

Fig. 1 の点線で囲まれた部分はNN によって線形化 されるシステムを表わすが, この未知線形化システムに 対するロバストな適応制御系をつぎのように構成する.

まず，未知線形化システムを

$$
\begin{aligned}
& y(k)=G\left(z^{-1}\right) u(k)=\frac{z^{-L} B\left(z^{-1}\right)}{A\left(z^{-1}\right)} u(k) \\
& A\left(z^{-1}\right)=1+a_{1} z^{-1}+\cdots+a_{n} z^{-n} \\
& B\left(z^{-1}\right)=b_{0}+b_{1} z^{-1}+\cdots+b_{m} z^{-m}
\end{aligned}
$$

のように表わせるとする。一方，規範モデルは

$$
\begin{aligned}
& y_{r}(k)=G_{r}\left(z^{-1}\right) r(k)=\frac{z^{-L} B_{r}\left(z^{-1}\right)}{A_{r}\left(z^{-1}\right)} r(k) \\
& A_{r}\left(z^{-1}\right)=1+\alpha_{1} z^{-1}+\cdots+\alpha_{n_{r}} z^{-n_{r}} \\
& B_{r}\left(z^{-1}\right)=\beta_{0}+\beta_{1} z^{-1}+\cdots+\beta_{m_{r}} z^{-m_{r}}
\end{aligned}
$$

とする.さらに，モニックな漸近安定な多項式

$$
D\left(z^{-1}\right)=1+d_{1} z^{-1}+\cdots+d_{n_{d}} z^{-n_{d}}
$$

を導入し, つぎの出力誤差

$$
e(k)=y(k)-y_{r}(k)
$$

を小さくする適応制御系を構成する.ここで通常のモデ ル規範形適応制御と同様な仮定を行う。このとき $(3)$ 式 に対応する線形化システムの入力表現は

$$
u(k-L)=\theta^{T} w(k)
$$

となる.ここで,

$$
\begin{aligned}
& \theta^{T} \equiv\left(b_{0}^{-1}, \theta_{2}, \theta_{3}, \cdots, \theta_{n+m+L}\right) \\
& w^{T}(k) \equiv\left(D\left(z^{-1}\right) y(k), u(k-L-1), \cdots,\right. \\
& \quad(k-m-2 L+1), y(k-L), \cdots, y(k-L-n+1))
\end{aligned}
$$

と执いた。 未知係数を後述の方法で調整することにより，

( 5 ) 式に対応する適応制御入力 $u(k)$ は

$$
\begin{aligned}
u(k)=\hat{\theta}^{T}(k) w_{r}(k+L) \\
\hat{\theta}^{T}(k) \equiv\left(\hat{b}_{0}^{-1}(k), \hat{\theta}_{2}(k), \cdots, \hat{\theta}_{n+m+L}(k)\right) \\
w_{r}^{T}(k+L) \equiv\left(D\left(z^{-1}\right) y_{r}(k+L), u(k-1), \cdots,\right. \\
u(k-m-L+1), y(k), \cdots, y(k-n+1))
\end{aligned}
$$

で表わせる.ここで, 拡張誤差 $\varepsilon(k)$ を

$$
\varepsilon(k)=u(k-L)-\widehat{\theta}^{T}(k-1) w(k)
$$

と定義しておく，制御対象に外乱が加わるときや，モデ ル化誤差がある場合には， $\hat{\theta}(k)$ の調整則に以下のよう な不感帯を入れたロバスト調整則が有効であることが知 られている16).

$$
\varepsilon^{\prime}(k)= \begin{cases}\varepsilon(k)-\delta-\gamma, & \text { if } \varepsilon(k)>\delta+\gamma \\ 0 & \text { if }|\varepsilon(k)| \leq \delta+\gamma \\ \varepsilon(k)+\delta+\gamma, & \text { if } \varepsilon(k)<-\delta-\gamma\end{cases}
$$

を用いて, 固定トレース形調整則

$$
\widehat{\theta}^{T}(k)=\widehat{\theta}^{T}(k-1)+\frac{\Gamma(k-1) w(k) \varepsilon^{\prime}(k)}{1+w^{T}(k) \Gamma(k-1) w(k)}
$$

$$
\tilde{\Gamma}(k)=\Gamma(k-1)-\frac{\Gamma(k-1) w(k) w^{T}(k) \Gamma(k-1)}{1+w^{T}(k) \Gamma(k-1) w(k)}
$$

$$
\Gamma(k)=\lambda^{-1}(k) \tilde{\Gamma}(k), \quad \lambda(k)=\operatorname{tr} \tilde{\Gamma}(k) / \operatorname{tr} \Gamma(0)
$$

を利用する. 不感帯の目的は, 誤差 $\varepsilon(k)$ がある值以下に なったらパラメー夕調整を停止することにより, 外乱や モデル化誤差に起因する不安定性を回避することにあ る.

\section{NN の学習における勾配の計算法}

非線形プラントを線形化する $\mathrm{NN}$ は， 3 層構造のもの を用いる， 2 章で述べたように，本稿では $\mathrm{NN}$ への入力 は,

$$
\begin{aligned}
& \left(u(k), v(k-1), \cdots, v(k-m), y_{r}(k+L), y(k-1),\right. \\
& \quad \cdots, y(k-n), 1) \equiv\left\{x_{i}(k)\right\}
\end{aligned}
$$

であり, NN は多入力 1 出力の非線形関数を表現でき る. $\mathrm{NN} へ$ の $i$ 番目の入力を $x_{i}(k)$, 入力層の $i$ 番目の ユニットから中間層の $j$ 番目のユニットへの重みを $w_{i j}^{(1)}(k)$, 中間層の $j$ 番目のユニットから出力層への重み を $w_{j}^{(2)}(k)$ とする。このとき，(6)式の右辺は

$$
\begin{aligned}
& \bar{u}(k)=\sum_{j=1}^{N} w_{j}^{(2)}(k) a_{j}(k) \\
& a_{j}(k)=f\left(\sum_{i=1}^{M} x_{i}(k) w_{i j}^{(1)}(k)\right)
\end{aligned}
$$

により表現できる.ここで, $f(\cdot)$ はシグモイド関数であ り, $f(x) \equiv 1 /(1+\exp (-x))$ で定義される.

$\mathrm{NN}$ の学習は, 制御対象の出力と規範モデルの出力と の二乗誤差が最小になるように行われる.すなわち

$$
E(k)=\frac{1}{2}\left(y(k)-y_{r}(k)\right)^{2}
$$

を最小にする重みの更新則は，

$$
\begin{aligned}
& w_{i j}^{(1)}(k+1)=w_{i j}^{(1)}(k)-\eta \frac{\partial E(k)}{\partial w_{i j}^{(1)}(k-L)} \\
& w_{j}^{(2)}(k+1)=w_{j}^{(2)}(k)-\eta \frac{\partial E(k)}{\partial w_{j}^{(2)}(k-L)}
\end{aligned}
$$

となる。ここで, $\eta$ は学習率といい, 各勾配は

$$
\begin{aligned}
\frac{\partial E(k)}{\partial w_{i j}^{(1)}(k-L)}= & \left(y(k)-y_{r}(k)\right) \frac{\partial y(k)}{\partial v(k-L)} w_{j}^{(2)}(k-L) \\
& \cdot a_{j}(k-L)\left(1-a_{j}(k-L)\right) x_{i}(k-L) \\
\frac{\partial E(k)}{\partial w_{j}^{(2)}(k-L)}= & \left(y(k)-y_{r}(k)\right) \frac{\partial y(k)}{\partial v(k-L)} a_{j}(k-L)
\end{aligned}
$$


で計算される，上式の計算では，制御対象の微分情報す なわち $\partial y(k) / \partial v(k-L)$ が必要になる.文献 8)では, この 微係数を得るために別に NN を準備し,オンラインで同 定を行っているが，本論文の手法では，学習を行う NN 自身の状態と適応制御の推定されたゲインパラメータよ りつぎのようにしてこの微係数が簡単に計算される点に 大きな特徴がある。

【補題 1】線形化システムが( 7 )式で与えられると き，出力の入力に関する微係数は次式を満たす。

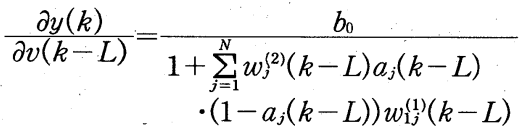

（証明）

$$
\begin{aligned}
& \text { まず, } u(k-L) \text { を媒介変数として } \\
& \frac{\partial y(k)}{\partial v(k-L)}=\frac{\partial y(k)}{\partial u(k-L)} / \frac{\partial v(k-L)}{\partial u(k-L)}
\end{aligned}
$$

と表わす. Fig. 1 の構造において, 制御入力 $v(k)$ が

$$
v(k-L)=u(k-L)+\bar{u}(k-L)
$$

で与えられることから，(18)式の分母は

$$
\frac{\partial v(k-L)}{\partial u(k-L)}=1+\frac{\partial \bar{u}(k-L)}{\partial u(k-L)}
$$

となる. $\partial \bar{u}(k-L) / \partial u(k-L)$ は NN の出力を入力で微 分したものであり，これはバックプロパゲーションを行 う場合と同様に，(15)式を微分することにより求めるこ とができる. 以上より，

$$
\begin{aligned}
\frac{\partial v(k-L)}{\partial u(k-L)}= & 1+\sum_{j=1}^{N} w_{j}^{(2)}(k-L) a_{j}(k-L) \\
& \cdot\left(1-a_{j}(k-L)\right) w_{1 j}^{(1)}(k-L)
\end{aligned}
$$

が求められる.

一方，(18)式の分子の方は, 線形化システムの入出力 関係が(10)式のモデルで表現できるならば,

$$
\frac{\partial y(k)}{\partial u(k-L)}=b_{0}
$$

となり，(18)〜 (20)式より補題が成り立つ.（証明終)

実際には， $b_{0}$ の推定值はすでに(14)式の適応制御の調 整パラメータの中で求められているので, これを利用す ればよい.

Fig. 1 の適応系は，(14)式の適応則と NN の (16) 式の 適応則とからなる。初期条件から制御対象が線形系であ る場合には，(14)式のほうが可調整パラメータの数も少 なく, NNの (16)式よりも非常に速く調整が終了するの で，NN はほとんど動作することなく，線形系に対する 適応則だけで規範モデルへのマッチングが達成できる。 一方，制御途中で対象が非線形系から線形系へ変化した 場合には, やはり (14) 式の調整がまずスタートするが, それまでの NN が非線形に対応するように学習されて いるため，(14)式の適応則だけでは出力誤差をゼロにで
きないので, 次第に NN が調整され出力誤差が小さくな るまで NN の出力が低下していく.これらの性質につい ては以下の適用例で説明する。

\section{5. 各種の非線形系への適用例}

\section{1 水槽のレベル制御への応用}

水槽の水位を目標值に追従させる制御系を考える。こ こで, 流出量 $q_{o}(t)$ と水槽の水位 $h(t)$ の間には, Fig. 2 に示すように, $q_{o}(t)=\alpha \sqrt{h(t)}$ なる非線形関係があるが, この関係は未知とする。また，規範モデルを $G_{r}\left(z^{-1}\right)$ $=0.4512 z^{-1} /\left(1-0.5488 z^{-1}\right)$, 適応制御における安定多項 式を $D\left(z^{-1}\right)=1-0.1 z^{-1}$ に設定し, $\mathrm{NN}$ の中間層のユ ニット数を $N=20$, ロバスト適応制御の不感帯の幅を $\delta$ $+\gamma=0.1$ とおいた．提案した方法の有効性を示すため に, 本手法を含めてつぎの四つの方法を比較検討した.

（a）定常動作点 $\left(h^{*}, q^{*}\right)$ における局所的な線形化モ デルが既知としたときのモデルマッチングによる線 形制御則。

（b）線形系に対するロバストなモデル規範形適応制御。

（c） 本手法：(a)の線形化モデルが既知としたときの 線形制御則と NN を組み合せた Fig. 1 の構造によ る方法.

（d） 本手法：(b)のロバストなモデル規範形適応制御 と NN を組み合せた Fig. 1 の構造による方法.

制御結果の計算例を Fig. 3 に示す. 既知線形化モデル を用いた手法 (a)では, 制御出力 $h(k)$ は規範出力 $h_{r}(k)$ より高めに制御されてしまうが，これは Fig. 2 の非線形 特性において局所線形化は流出量を必ず過大に評価する ことになり，そのため流入制御量が過大となり一般に目 標値より高めに制御されてしまうからである.（b)の適 応制御は線形化モデルが末知でも適用できるが，ロバス

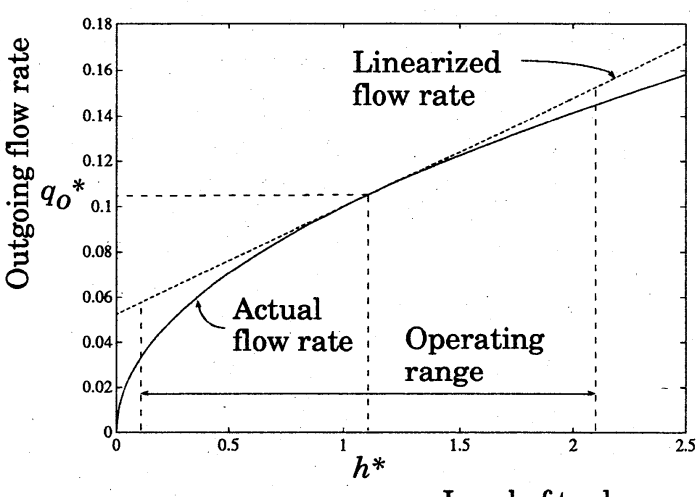

Level of tank

Fig. 2 Nonlinear characteristics between outgoing flow rate and level of tank 


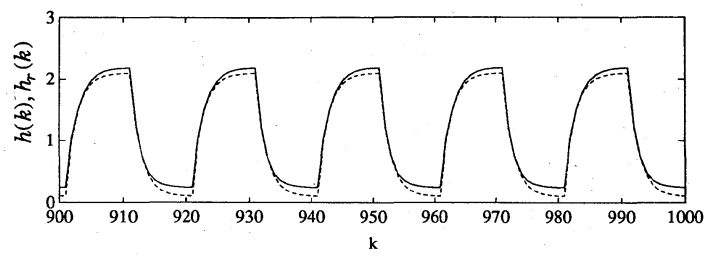

(a) Linear model matching based on known model linearized at $\left(h^{*}, q_{o}^{*}\right)$

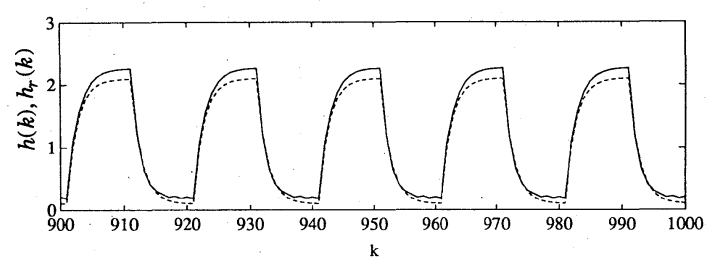

(b) Ordinary robust adaptive control

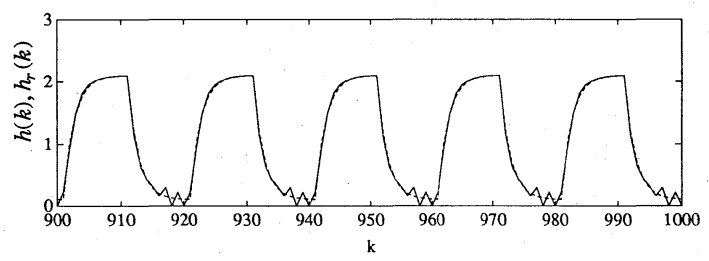

(c) Linear model matching (a) with nonlinearity compensation by $\mathrm{NN}$

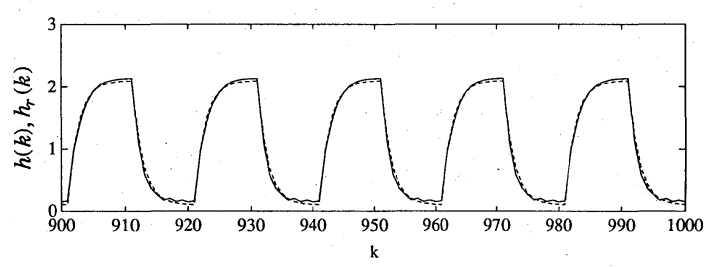

(d) Robust adaptive control (c) with nonlinearity compensation by $\mathrm{NN}$

Fig. 3 Profiles of controlled output $h(k)$ (solid line) and reference output $h_{r}(k)$ (dotted line)

ト性の確保から導入した不感帯のためにやはり ( a ) と同 様に $h(k)$ を $h_{r}(k)$ より高めに制御してしまう. NNを 組み入れた本手法で ( c )の場合は低い水位でハンティン グが生じているが，(d)のロバスト適応制御と NN を組 み合せた場合には非常に良好な追従特性が得られた。図 示していないが, 出力誤差 $e(k)$ により学習された $\mathrm{NN}$ の出力 $\bar{u}(k)$ が負值をとることにより, 線形制御による 過大な入力を補償しているのである.

\section{2 バックラッシュ特性の補償}

Fig. 4 に示すバックラッシュの非線形特性を有する入 力部と線形部とからなるいずれも未知である制御対象を 考える. 線形部, 規範モデルをそれぞれ

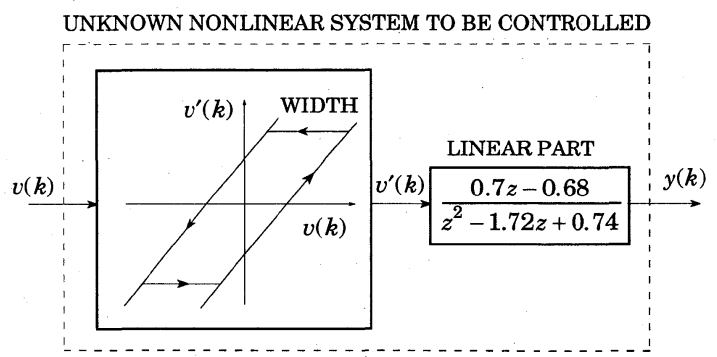

Fig. 4 Unknown controlled system with backlash in input part

$$
\begin{aligned}
& G\left(z^{-1}\right)=\frac{0.7 z^{-1}-0.68 z^{-2}}{1-1.72 z^{-1}+0.74 z^{-2}} \\
& G_{r}\left(z^{-1}\right)=\frac{z^{-1}+0.8 z^{-2}}{1+0.2 z^{-1}-0.63 z^{-2}}
\end{aligned}
$$
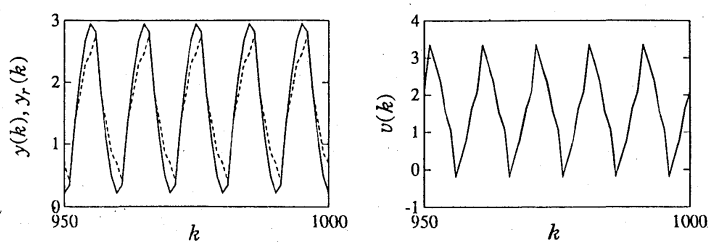

(a) Linear model matching assuming linear part is known
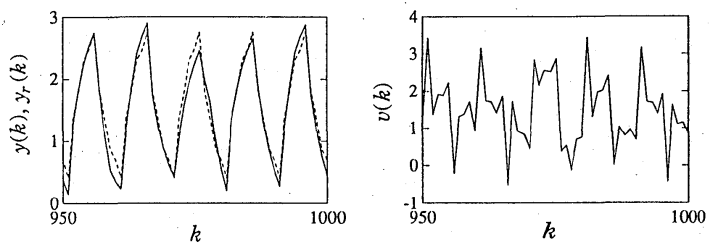

(b) Ordinary robust adaptive control
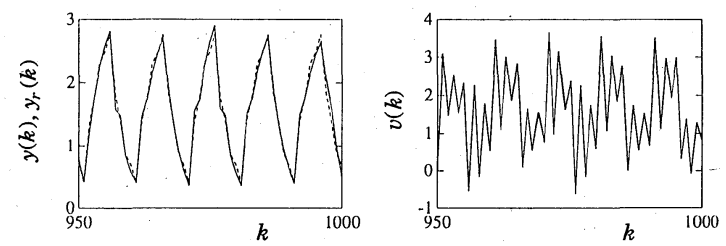

(c) Proposed scheme (1) consisting of NN and linear model-matching control
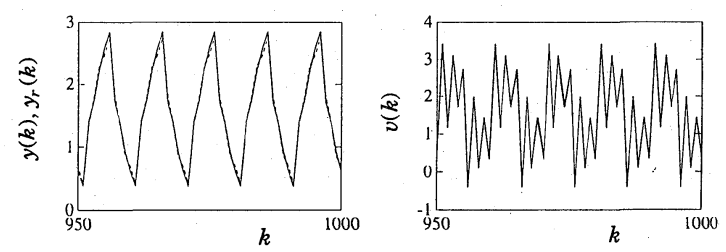

(d) Proposed scheme (2) consisting of $\mathrm{NN}$ and robust adaptive control

Fig. 5 (Left) Profiles of controlled output $y(k)$ (solid lines) and reference output $y_{r}(k)$ (dotted lines). (Right) Rrofiles of control input $v(k)$. 
と設定し, $D\left(z^{-1}\right)=1-0.1 z^{-1}, N=10, \delta+\gamma=1.1$ とおい た.Fig. 5 に計算結果を図示したが,つぎの四つの場合を 比較している。

（a）制御対象の線形部が既知として設計されたモデル マッチングによる線形制御則。

（b）モデル規範形ロバスト適応制御。

（c） 本手法：線形部が既知とした線形制御と NNを 組み合せた Fig. 1 の構造による方法.

（d） 本手法：ロバスト適応制御と NN を組み合せた

Fig. 1 の構造による方法.

各場合について, Fig. 5 の左側に規範出力 $y_{r}(k)$ (点 線)と制御出力 $y(k)$ (実線)をプロットし, 右側にはそれ ぞれの制御入力 $v(k)$ をプロットした，通常の線形制御 (a)では制御入力が滑らかとなり，バックラッシュ特性 を全く補償することができない。ロバス卜適応制御 ( b ) も規範出力への追従特性は良くない. 一方，(c)，（d） のように NN を用いた本手法では規範出力への追従特 性がきわめて改善されていることがわかる．NNによる 制御入力は，(a)，（b)、比較してかなり振動的になっ ている点に大きな特徴があるが，これはバックラッシュ の幅を越えて入力を往復させることにより入出力間を等

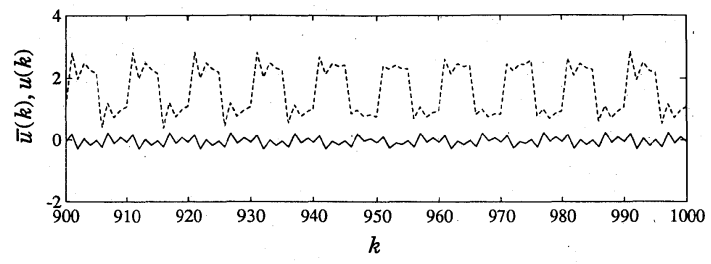

(a) Backlash width: 0.4

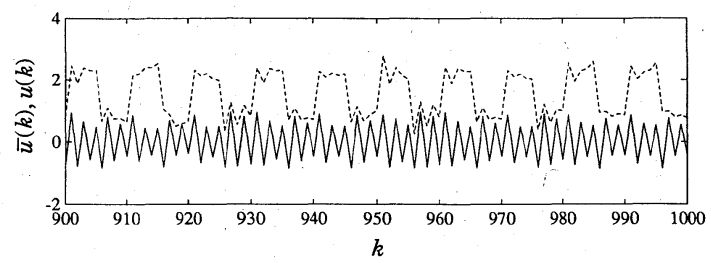

(b) Backlash width : 1.6

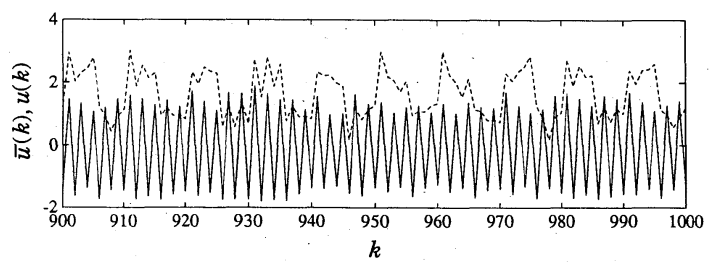

(c) Backlash width: 3.2

Fig. 6 Profiles of control input $v(k)=u(k)+\bar{u}(k), \bar{u}(k)$ : output of NN (solid lines), and $u(k)$ : adaptive control (dotted lines) for various width of backlash in use of scheme $(d)$

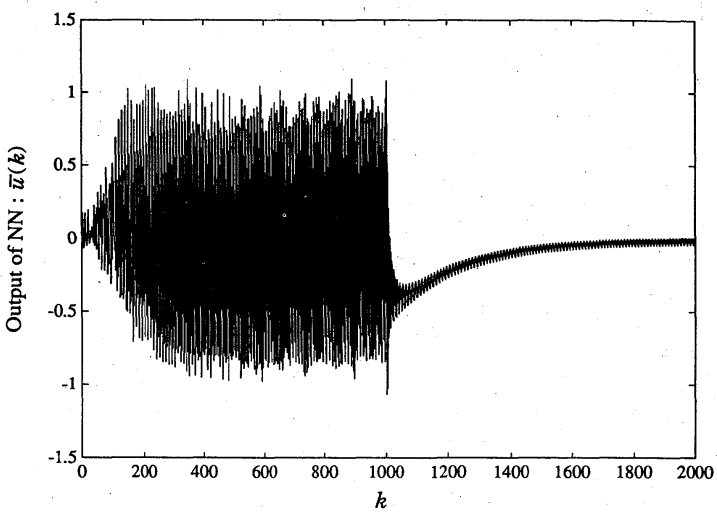

Fig. 7 Response profile of output of NN $\bar{u}(k)$ when backlash is removed at $k=1000$

価的に線形化していると考光られる．Fig. 6 に示すよう に, 実際にバックラッシュの幅を, 0.4, 1.6, 3.2 と大きく するにつれて NN の出力 $\bar{u}(k)$ の振幅はかなり大きく なるが，線形コントローラの出力 $u(k)$ はほとんど変わ らない.これは NN が非線形性の補償に主として寄与し ていること，および線形化されたモデルが実際にほぼ 線形系として動作していることを示している。さらに，

Fig. 7 には, 時刻 $k=1000$ でバックラッシュの非線形性 を除去したときの NN の出力 $\bar{u}(k)$ の変化をみたもの であり，非線形特性が消滅すると自動的に NN は急速に ほとんど動作しなくなるのである。線形系に関して NN が機能しない点については付録を参照されたい.

\section{3 入力非分離形非線形特性をもつ場合}

文献 9)で扱われているつぎの非線形系を考える.

$$
\begin{aligned}
& y(k+1)=f(y(k), y(k-1), y(k-2), u(k), u(k-1)) \\
& f\left(x_{1}, x_{2}, x_{3}, x_{4}, x_{5}\right)=\frac{x_{1} x_{2} x_{3} x_{5}\left(x_{3}-1\right)+x_{4}}{1+x_{3}^{2}+x_{2}^{2}}
\end{aligned}
$$

ここで, $G_{r}\left(z^{-1}\right)=0.57 z^{-1} /\left(1-0.4493 z^{-1}\right), D\left(z^{-1}\right)=1$ $-0.5 z^{-1}, N=25, \delta+\gamma=0.3$ と設定した. Fig. 8 には, 前例と同様に, (a) ロバスト適応制御のみによる結果,

（b) NN を併用した本手法による結果を比較して示し た。線形系に対する適応制御では追従できないが，(b) に示すようにNN の補償によりほぼ規範出力への追従 が達成されている。このときの制御入力 $v(k)=u(k)$ $+\bar{u}(k)$ を構成する $\bar{u}(k)$ (実線: NN の出力) と $u(k)$ (破線：適応制御入力）を別々にプロットした，適応制御 $u(k)$ が規範出力の正弦波に近い正弦波を発生している ことから, Fig.1の破線のブロックはほほ線形化されて いると判断される．したがって，正と負の部分で異なる 歪んだ制御入力を NNにより発生させて非線形特性を 補償していることがわかる. 


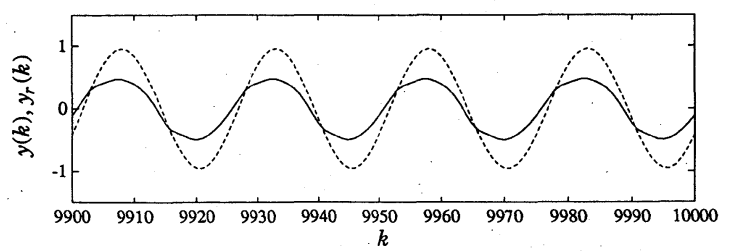

(a) Ordinary robust adaptive control

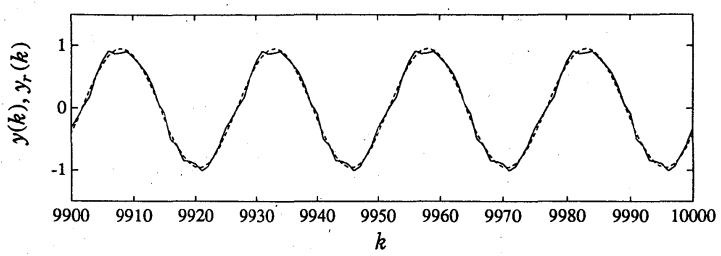

(b) Robust adaptive control with nonlinearity compensation by $\mathrm{NN}$

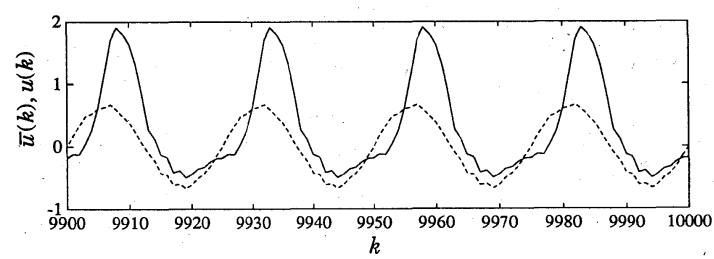

(c) Profiles of NN output $\bar{u}(k)$ and adaptive control $u(k)$ in case ( $\mathrm{b})$

Fig. 8 Comparison of schemes (a) and ( b ) in profiles of output $y(k)$ (solid lines) and reference output $y_{r}(k)$ (dotted lines). (c) Profiles of $\bar{u}(k)$ (solid line) and $u(k)$ (dotted line) where control input is given by $v(k)=u(k)+\bar{u}(k)$.

\section{4 局所線形化モデルが不可制御の場合}

つぎの適用例も文献 9)で採りあげられたものである.

$$
y(k+1)=\frac{y(k)}{1+y^{2}(k)}+u^{3}(k)
$$

で与えられる非線形系に対して本手法を適用する。上式 からわかるように, $u=y=0$ で線形化すると, $y(k+1)$ $=y(k)$ となり, この近傍では制御しにくい系である. 規 範モデルを $G_{r}\left(z^{-1}\right)=z^{-1} /\left(1-0.6 z^{-1}\right)$, 安定多項式を $D\left(z^{-1}\right)=1-0.5 z^{-1}$, さらに $N=50, \delta+\gamma=1.8$ に設定し た. Fig. 9 には，(a) ロバスト適応制御のみによる結果， (b) NN を併用した本手法による結果を比較して示し た. 適応制御では $u(k)$ が 1 を越えたときの過大な入力 のために出力に大きなオーバシュートが生じるが, NN を組み合せた場合に, NN の出力により過大な入力を抑 制しているのである。

\section{6. 結 論}

非線形の制御対象を含む入出力特性を任意の線形規範 モデルに一致させる適応制御において制御入力を $\mathrm{NN}$

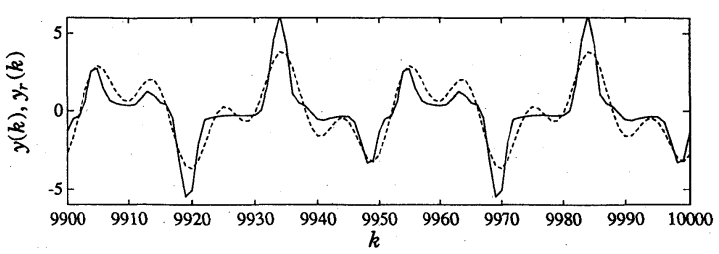

(a) Ordinary robust adaptive control

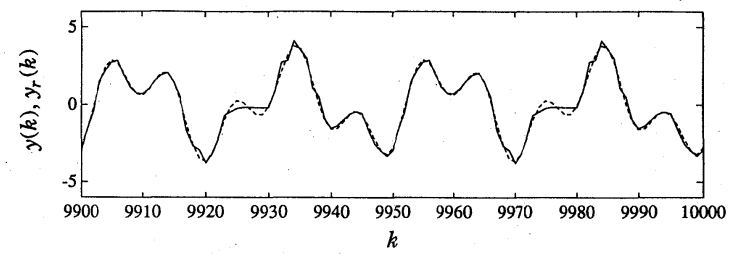

(b) Robust adaptive control with nonlinearity compensation by NN

Fig. 9 Profiles of controlled output $y(k)$ (solid lines) and reference output $y_{r}(k)$ (dotted lines)

の出力とロバスト適応制御器の出力の和によって与える 新しい構造をもつ構成法を提案した.この方法の最大の 特徴は, NN の学習の際に必要な非線形系の入力に関す る出力の微分係数を, 実時間で得られる線形化モデルの ゲイシ係数と NN の内部状態とを用いて容易に計算で きる点にあるを明らかにした。これによりバックプロパ ゲーション法をきわめて効率よく実施することが可能と なった。 また提案する構造においては， NN に非線形性 のみを補償する機能をもたせており，制御対象が線形系 に近ければ, 適応制御器が主に機能し, NN ほほとんど 動作しないという特徴も示した。

本論文では勾配法に基づく学習法について述べたが， 文献 4)などのような最小 2 乗法形のアルゴリズムにも 適用できる．また外乱に対する処理としては，NNの勾 配法にも適応制御則で用いた不感帯を導入しロバスト性 を高め, 固定補償要素により外乱補償を行う方法 ${ }^{17)}$ が有 効であることを付記しておく. 本手法による NN の汎化 能力に関しては, 目標値の振幅やその時間波形を変えた りしても，NN はわずかな学習時間で対応できることは 確認しているが, 汎用能力は規範入力が十分に多くの周 波数成分をもつという $\mathrm{PE}$ 性条件とも関係すると思われ るので, 今後の検討課題としたい.

\section{参 考 文 献}

1) E. Sanchez-Sinencio and C. Lau, ed. : Artificial Neural Networks, IEEE Press (1992)

2) 大松 繁: ニューラルネットワークと適応制御, コン ピュトロール, 32 (適応制御), 73/79 (1990)

3) M. Kawato, K. Furukawa and R. Suzuki : A Hierarchical Neural Network Model for Control and Learning of Voluntary Movement, Biol. Cybern., 57, 169/185 (1987) 
4) S. Chen, S. A. Billings and P. M. Grant: Nonlinear System Identification Using Neural Network, Int. J. Control, 51-6, 1191/1214 (1990)

5) S. R. Chu, R. Shoureshi and M. Tenorio: Neural Networks for System Identification, IEEE Contr. Syst. Mag., 10-3, 31/35 (1990)

6) Y. Iguchi and H. Sakai : A Nonlinear Rehulator Design in the Presence of System Uncertainties Using Multilayered Neural Networks, IEEE Trans. Neural Networks, 2-4, 4/27 (1990)

7) L. G. Kraft and D. P. Campagna: A Comparison Between CNAC Neural Network Control and Two Traditional Adaptive Control Systems, IEEE Control Systems Magazine, 10-3, 36/43 (1990)

8) F. C. Chen : Back-Propagation Neural Networks for Nonlinear Self-Tuning Adaptive Control, IEEE Contr. Syst. Mag., 10-3, 44/48 (1990)

9) K. S. Narendra and K. Parthasarathy : Identification and Control of Dynamical Systems Using Neural Networks. IEEE Trans. Neural Networks, 1-1, 4/27 (1990)

10) L. Jin, P. N. Nikiforuk and M. M. Gupta: Adaptive Tracking of SISO Nonlinear Systems Using Multilayered Neural Network, Proc. ACC-92, 56/60 (1992)

11) K. J. Hunt and D. Sbarbaro: Neural Networks for Nonlinear Internal Model Control, IEE Proc., Ser. D, 138-5, 431/438 (1991)

12）山田, 薮田：ダイレクトニューロコントローラに関する 一考察, 計測自動制御学会論文集, 27-7, 784/791 (1991)

13）山下, 島, 石動: ニューラルネットワークによる学習・適 応制御, 計測と制御, 30-4, 302/308 (1991)

14）新, 西村: 離散時間非線形系に対するニューロアダプ ティブコントロール, 第 20 回制御理論シンポジウム資料, 283/286 (1991)

15）辻, 大森, 佐野：ニューラルネットワークによる非線形補 償を有するモデル規範形適応制御，第 21 回制御理論シン ポジウム資料, 311/316（1992）

16) G. Kreisselmeier and B. D. O. Anderson : Robust Model Reference Adaptive Control, IEEE Transactions, Automatic Control, AC-31-2, 127/133 (1986)

17）大森, 佐野: 確定未知外乱の補償を考慮したモデル規範 形適応制御, 計測自動制御学会論文集, 20-10, 919/925 (1984)

\section{《付録》}

いま，制御対象自体が ( 7 )式の線形系で与えられると

し，（8)式の規範モデルにマッチングさせる問題を考え

る。このとき, Fig. 1 の構造より次式が成り立つ。

$$
A\left(z^{-1}\right) y(k)=z^{-L} B\left(z^{-1}\right)(u(k)+\bar{u}(k)) \quad(\mathrm{A} 1 \text { ) }
$$

ここで, $D\left(z^{-1}\right) e(k+L)$ をゼロとする制御入力 $u(k)$ は, モデルマッチングの条件より,

$$
D\left(z^{-1}\right) y_{r}(k+L)=R\left(z^{-1}\right) B\left(z^{-1}\right) u(k)+S\left(z^{-1}\right) y(k)
$$

を満たす。ただし， $R\left(z^{-1}\right)$ と $S\left(z^{-1}\right)$ は多項式で，つぎの ベゾー方程式

$$
D\left(z^{-1}\right)=A\left(z^{-1}\right) R\left(z^{-1}\right)+z^{-L} S\left(z^{-1}\right)
$$

の解である。(A 1) (A 2) 式より，

$$
D\left(z^{-1}\right) e(k+L)=R\left(z^{-1}\right) B\left(z^{-1}\right) \bar{u}(k)
$$

となり, $R\left(z^{-1}\right)$ が安定(コントローラが安定)ならば, 出 力誤差 $e(k)$ をゼロにすることは, NN の出力 $\bar{u}(k)$ をゼ ロにすることと同じことがわかる。

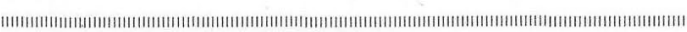

$$
\text { [著 者 紹 介] }
$$

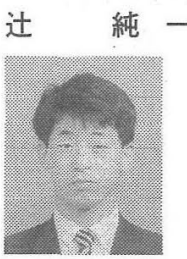

1990 年, 慶應義塾大学理工学部電気工学 科卒業。92 年同大学大学院修士課程修了. 同年東京電力(株)に入社，現在は同社東京 東支店墨東総合制御所勤務。在学中は ニューラルネットワークに関する研究に従 事.

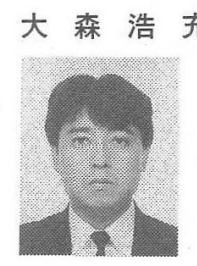

\section{（正会員）}

1993 年, 慶應義塾大学工学部電気工学科 卒業。 88 年同大学大学院博士課程修了 (工 学博士). 同年同大学理工学部助手. 91 年同 講師。適応制御理論, ロバスト制御理論, およびこれらの応用に関する研究に従事。 電子情報通信学会, 電気学会, システム制 御情報学会, IEEEなどの会員。

佐 野昭（正会員）

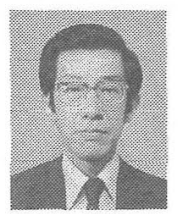

1966 年, 東京大学工学部計数工学科卒 業。71年同大学院博士課程修了 (工学博 士). 同年慶應義塾大学工学部助手. 専任講 師, 助教授を経て，85 年同理工学部教授。 適応制御などの制御系設計論，システム同 定, 信号処理論, 生体治療制御などの研究 に従事。電子情報通信学会, 電気学会, シ ステム制御情報学会, IEEE, EURASIP な どの会員。

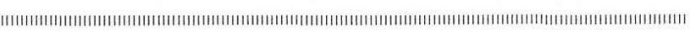

